\title{
THE ENERGY DIPLOMACY OF UKRAINE AS AN EFFECTIVE AND POWERFUL TOOL FOR IMPROVING NATIONAL ENERGY SECURITY
}

\begin{abstract}
This article reveals the essence of energy diplomacy in Ukraine to be an effective and powerful tool for improving national energy security. The focus lies on an analysis of the European energy diplomacy rules that presuppose the ability to take into account the interests of all parties, including the interests of Ukraine, which comply with European legislation and should be considered as an integral part of the EU gas market. With a powerful resource, it is a transit country for' the transportation of gas, Ukraine needs to concentrate all its efforts on maintaining the status of a geopolitical player. However, playing by European rules requires compliance with European standards on the organization of gas production and transportation. Currently, Ukraine has been developing an proactive energy diplomacy strategy that faces external challenges and threats. While playing a crucial role as a strategic geopolitical gas transit country, Ukraine requires the use of proactive strategies to advance the agenda for European energy security. To conclude, it is necessary that Ukraine should vigorously develop suitable energy diplomacy as an effective tool for improving energy security both on the national and European levels.
\end{abstract}

\section{Key words}

energy diplomacy, gas transportation system, transit country' Ukraine, energy diplomacy, energy strategy, national energy security 


\section{Introduction}

It should be stated that the key point of integrating "energy security" into the system of international relations and the foreign policies of national powers has become quite evident since the Middle East Oil Crisis (1973-74). From then, energy resources gained importance not only as strategic raw materials but as a push and pull factor of powerful foreign policy. It is noteworthy that the International Energy Agency (IEA) has become the first institutionalized energy security supplier to grant a large amount of authority in the field of energy security, which is covered by the Agreement on an International Energy Program (2007). The actions of the IEA have led to the necessity for coordination of energy cooperation between developed countries in the security field, above all regarding issues of "security of supply, long term policy, information 'transparency', energy and the environment, research and development, international energy relations" (Scott, 2010, p. 12). The IEA defines energy security as the "uninterrupted availability of energy resources at an affordable price" (International Energy Agency..., 2019) and structurally divides it into long-term energy security related to "timely investments to supply energy in line with economic developments and environmental needs", and short-term energy security, the core of which is the "ability of the energy system to react promptly to sudden changes in the supply-demand balance” (International Energy Agency..., 2019).

The problem of enhancing a stable space for energy security in the EU has become a priority in its foreign policy since the outset of the Ukraine-Russia gas disputes. From a historical perspective, the first conflict occurred between 2004 and 2005. When the Russian gas supplier Gazprom and the Ukrainian stateowned oil and gas company, Naftogaz, failed to agree on price, use and transportation for the common EU market, European experts have rated the conflict as a start of "'a full-blown geopolitical crisis"” (Study of the EU's energy diplomacy: Transatlantic and foreign policy implications, 2016, p. 16). Shortly after, according to the Report of the Implementation of the European Security Strategy: Providing Security in a Changing World (2008), energy security was defined in terms of threat and risk factors. It was predicted that by 2030, the EU will import nearly a third of its oil and gas from a limited number of countries (Shared Vision, Common Action..., 2016).

The annexation of Crimea and the Russian Federation's aggression in the east of Ukraine aggravated the problem of EU energy security, above all the aspect concerning Russia's foreign policy that has transformed economic energy 
resources onto a political level has been considered a pressing issue. Considering Ukraine, Russian aggression has become a challenge for preserving and establishing the status of a transit country in the chain of international relations Export country (Russia) - Transit country (Ukraine) - Import countries (EU). Recognizing Ukraine's geopolitical status as a gas-transit country, its energy security is a crucial step in effective energy diplomacy.

\section{Methodology}

The subject of the study is energy diplomacy as an effective tool for improving energy security in Ukraine, and this leads to the definitions of two categories which are crucial for studying the premises of geopolitics, energy diplomacy and security, as Ukraine is a gas-transit country in the context of its European aspirations.

In modern political science, the essence of "energy diplomacy" is based on its role as an effective tool of foreign state policy, regardless of Ukraine being an importer or exporter of fuel and energy resources (Constantinou, Kerr \& Sharp, 2016; Proedrou, 2017). Accordingly, this category examines, on the one hand, the place of a nation as a consumer and its energy security, and on the other, the position of exporting countries that can potentially use the energy factor as an "oil/gas weapon" and a lever of political pressure on importing countries (Pirani, Stern \& Yafimava, 2009). Achieving parity of interests of exporting countries that are capable of using energy resources to secure their political goals in international relations (Ahmed, Abdulsamd, Gereffi, \& Daly, 2014; Larsson, 2006; Zhiznin, 2010), and importing countries seeking to prioritize their interests (Auer, 2007; Chaban \& Knodt, 2015) can only result in an effective energy diplomacy. In this case, the objective of diplomatic interaction is to ensure engagement in the development of all energy resources and their processing, transportation and distribution processes, for both the exporting and importing country (Bayou, 2007; Cleutinx \& Piper, 2008; Goldstone, 2007; Simoniya \& Torkunov, 2015).

Consequently, the concept of "energy diplomacy" fully reflects and characterizes all the processes that take place in the global energy market. However, the conceptualization of the term "energy diplomacy" in modern political science does not imply a definition of the status and interests of the energy transit countries and those potentially specific methods and technologies that are capable of ensuring an adequate level of national security for those countries. As can be seen, "energy security" is a critical concern for the collective security, 
safety and protection of a state, a society and each of its citizens, from internal and external threats and risks to a stable and regular energy supply and becomes a question of national and economic security (Hartley \& Medlock III, 2006). To identify security as the context and purpose of Ukraine's energy diplomacy, critical studies of security that extend security research have been applied, while 1) publicly putting an emphasis on issues of security (including energy security); 2) integrating the problems of regulatory policy in the context of shaping energy diplomacy (McSweeney, 1996).

\section{European energy diplomacy: the Ukrainian paradigm}

If considering a model of energy diplomacy for emulation, Ukraine, in the context of its European aspirations, should definitely take advantage of the EU's established effective energy diplomacy. According to EU political practice and social experience, the concept of energy diplomacy is integrated into EU legislation. To be more precise, A Framework Strategy for a Resilient Energy Union with a Forward-Looking Climate Change Policy (2015), known as the Energy Union Strategic Framework, strikes the right balance between different objectives: affordable energy, safe and secure energy systems, European competitiveness, sustainability and the transition towards a more climate friendly economy. Accordingly, the top priorities of EU energy diplomacy are directed "to establish strategic energy partnerships with increasingly important producing and transit countries or regions such as Algeria and Turkey; Azerbaijan and Turkmenistan; the Middle East; Africa and other potential suppliers" (A Framework Strategy..., 2015). "The Energy Union in fifteen action points", concluding A Framework Strategy for a Resilient Energy Union with a Forward-Looking Climate Change Policy, stressed the EU's need to strive to use all external policy instruments and have the unity to form a strategy that "speaks with one voice on energy" (A Framework Strategy..., 2015). Furthermore, it was suggested that a fully functioning internal energy market should constitute the core of the energy union.

Admittedly, since 2014, Russia's invasion and partial occupation of Ukraine's territory, has demonstrated the relevance of energy diplomacy tools to lower risks in the EU energy security domain. The Energy Diplomacy Action Plan approved by the Council of the EU appeared to be a political mirroring of the energy strategy. In view of that, the main energy diplomacy directions are a strengthening of the strategic management in the energy field by high level influence; energy cooperation in order to diversify sources and providers; efforts to strengthen 
the global energy architecture; and the formation of common ideas and effort towards consolidation in the sphere of energy diplomacy (Study of the EU's energy diplomacy..., 2016, p. 11). The European Council offers to control the EU Energy Diplomacy Action Plan by strict monitoring and coordination with EU members. It should be noted that a significant aspect of European energy diplomacy is an acknowledgement of EU dependency on Russian gas supplies. Obviously, the EU will be finding ways to maintain overall control of their market, therefore "a critical dialogue with Russia needs to be part of European energy diplomacy" (Study the EU's energy diplomacy..., 2016, p. 11).

\section{Ukrainian Energy Diplomacy: Energy Resources}

According to the classical interpretation, Ukrainian energy diplomacy is aimed at securing national energy security, managing the permanent delivery of energy resources, providing diversification for suppliers of energy resources, involvement in global energy dialogue, synchronizing Ukrainian and EU energy policies, providing international market access for new energy technologies, involvement in energy investment, etc.

The primary energy resource of Ukrainian energy diplomacy is its gas transportation system (GTS), one of the most powerful in the world (Table 1): its input capacity reaches $287.7 \mathrm{bcm}$ per year, with output towards European countries of $151.4 \mathrm{bcm}$ per year (Naftogaz..., 2015). In fact, the past 50 years have seen it as the main natural-gas pipeline from the Russian Federation to European countries. The technologies used as well as the flexibility and stability of this transport system have made it the optimal route for gas delivery. The GTS is tightly connected with neighbouring countries' gas systems: the Russian Federation, Poland, Romania, Moldova, Hungary, Slovakia; and through them it is integrated into the European gas network.

Thus, Table 1 shows that the length of the main gas pipelines of Ukraine GTS and its branches is $37,600 \mathrm{~km}$. The GTS includes 1473 gas-distribution stations. The facilities of its gas compressor stations include 702 pumping units with a total capacity of $5496 \mathrm{MW}$ located at 73 compressor stations, which include 110 compressor units. The company has implemented an integrated system of quality and environmental management in compliance with the requirements of ISO 9001, OHSAS 18000 and ISO 14001. Since 2011, despite the capacity of the Ukrainian GTS, the Russian Federation, guided by political rather than economic considerations, has continually reduced volumes of gas to the EU via the territory of Ukraine (Fig. 1). 
Table 1. The basic characteristics of the gas transportation system in Ukraine

\begin{tabular}{|c|c|c|}
\hline Parameters & Unit & Amount \\
\hline length of gas pipelines ${ }^{\star}$ total: & \multirow{5}{*}{$\mathrm{km}$} & $37,600,177$ \\
\hline including: & & including: \\
\hline main gas pipelines & & $22,007,472$ \\
\hline final delivery pipeline & & $13,123,527$ \\
\hline feeder lines & & $2,469,178$ \\
\hline compressor stations & unit & 73 \\
\hline compressor workshops & unit & 111 \\
\hline gas compressor units & unit & 705 \\
\hline the capacity of pump stations & MW & 5496 \\
\hline gas-distribution stations & unit & 1473 \\
\hline
\end{tabular}

Source: Description of the gas-transport system of Ukraine (2019). Retrieved from http://utg.ua/ utg/gts/description/

* Note: gas pipeline length is based on the length of the pipelines from THE (Crimea) and TNT Ukraine (ORDA) - the results of an inventory, dated December 31, 2017

Fig. 1. Changes in natural gas transit via the Ukrainian GTS (gas transit system) to Europe in billion cubic meters ( $\mathrm{bcm})$

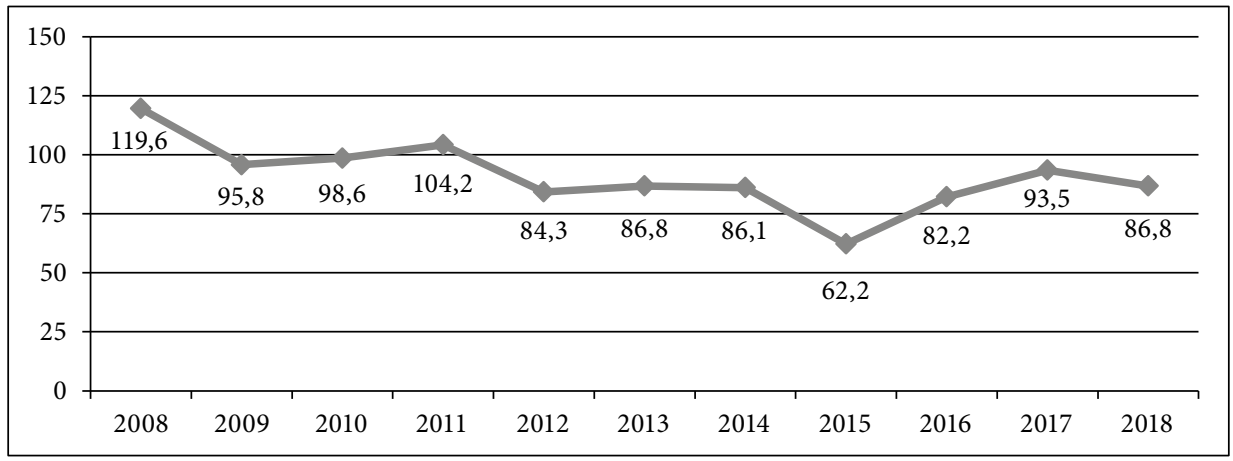

Source: Available at: Annual report of 2016. The first stirrings of the [national joint campaign NAFOGAZ of Ukraine]. (2017). Retrieved from http://www.naftogaz.com/files/Zvity/Anual_report_ukr_170608.pdf; Annual report 2017. A historic victory and the beginning of the transformation of the [national joint campaign NAFOGAZ of Ukraine]. (2018). Retrieved from http:// www.naftogaz.com/files/Zvity/NAK_AnRep2017_UA.pdf; Annual report 2018. Strengthen yourself - Ukraine [national joint campaign NAFOGAZ of Ukraine]. (2019). Retrieved from http://www.naftogaz.com/files/Zvity/Annual-Report-2018-ukr.pdf 
Analyzing the data shown in Fig. 1, it can be argued that, firstly, the transportation of gas via Ukraine in 2014 decreased by almost 25\% from $86.1 \mathrm{bcm}$ in 2013 to $62.2 \mathrm{bcm}$ in 2014. After significant reductions in transit via Ukraine in 2014, in 2015 the volume increased to $64.2 \mathrm{bcm}$, which is almost $8 \%$ more than in 2014 . Secondly, in 2016 the demand for gas in Europe increased, in particular due to growing prices for alternative energy sources, while domestic gas production in the EU remained at a record low level. This was connected with the restrictive measures by the Netherlands government which significantly reduced the volume of production in the Groningen field from 27 to $24 \mathrm{bcm}$ (BP 2019). In this context, the price of the Russian gas import to Europe $(178.3 \mathrm{bcm})$ skyrocketed (Delivery statistics..., 2018), while imports from Norway remained at the same level as in 2015 at $108 \mathrm{bcm}$ (Annual Report and Form 20-F 2016-2017). Thirdly, in 2017, the transit of Russian gas via Ukraine rose to $14 \%$ due to the increase in gas consumption in the European market because of weather conditions (Gas prices by type of user..., 2019). In 2018, the volume of transit of Russian gas via Ukraine totalled $86.8 \mathrm{bcm}, 6.7 \mathrm{bcm}$ less than the transit volumes in 2017. Therefore, the cutback in transit volumes is due, primarily, to greater use of Russian capacity of the Nord Stream 2 pipeline while the reduction in gas consumption in the EU in 2018 is $2.4 \%$ (Gas prices by type of user..., 2019).

Of particular value to the Ukrainian GTS as a resource for energy diplomacy is that on the Western border of Ukraine transit gas goes to Gazprom Export (subsidiary of Gazprom), which provides in advance shipping codes to European operators. Thus, Gazprom undertook a number of the important functions of the operator GTS, which is a violation of European energy legislation because it creates limitations on full cooperation between the operators of neighbouring countries on the territory of the Energy Community. Secondly, it creates artificial restrictions on the free flow of gas between Ukraine and the EU; in particular, the virtual reverse flow of gas or set-offs. Presently, European buyers not only are unable to choose the route of gas delivery, but they also do not have the ability to dispose of gas acquired in the Russian Federation until it crosses the Ukraine border. This deprives them of the opportunity to use Europe's largest Ukrainian underground gas storage facilities and limits their ability to trade on the Ukrainian market.

In these circumstances, the purpose of Naftogaz in Ukraine is to minimize the political component on the domestic gas market and relations with external partners. The company is working on bringing relations between the operators of adjacent structures on the border of Ukraine into accordance with the norms of the Third Energy Package. This will allow gas buyers on both sides of the border 
to use the virtual reverse flow and eliminate artificial barriers to transporting gas to Central, Southern and Eastern Europe.

In May 2015, the company and the Hungarian operator FGSZ signed the first agreement on the joining of cross-border pipelines between Ukraine and Hungary (Interconnector agreement). This transaction was the first crucial step to establish collaboration between Ukrtransgaz and neighbouring operators of the GTS. Contracts on interconnectors are the only legal basis for operational cooperation between the operators of interconnected gas transport systems of member countries of the Energy Community. Such cooperation involves the exchange of information about gas flows, their direction, quantity, time, customers, recipients, and the like. Ukraine is currently working on signing similar agreements with the Slovak, Polish and Romanian operators.

Therefore, a strategic priority for energy diplomacy is the full integration of its most important resource, the Ukrainian GTS, into the European GTS. The operator of the Ukrainian GTS should work directly with all adjacent GTS operators, complying with European legislation.

\section{The energy diplomacy of Ukraine: the energy issue}

The domain of Ukrainian energy diplomacy is quite variable. To the author's knowledge, its essence is derived from Ukraine's need to maintain its status as a transit country for Russian gas to the EU (Fig. 1). Accordingly, the key elements of energy diplomacy of Ukraine, which influences the preservation/ change/loss of the geopolitical status of Ukraine as a transit country, are the most important. These include (1) Nord Stream 2, (2) Turkish Stream, (3) Stockholm Arbitration.

Nord stream 2 pipeline. Russian implementation of the Nord Stream 2 construction project, a gas export pipeline from the Russian Federation to Europe through the Baltic Sea, passing into German territory in the Greifswald region, has a negative impact on the status of Ukraine as a gas transit country. In 2015 Gazprom alongside five Western European companies (BASF, E. ON, ENGIE, OMV, and Shell) agreed to jointly implement the project, planning that the combined capacity of the two Nord Stream 2 branches would be $55-60 \mathrm{bcm}$ per year. Besides, it has announced an increase in the volume of the Nord Stream previously constructed to $60 \mathrm{bcm}$. As a consequence, the total project capacity of Nord Stream and Nord Stream 2 can reach $110-120 \mathrm{bcm}$ per year. 
Fig. 1. Gas transportation routes from Russia to Europe

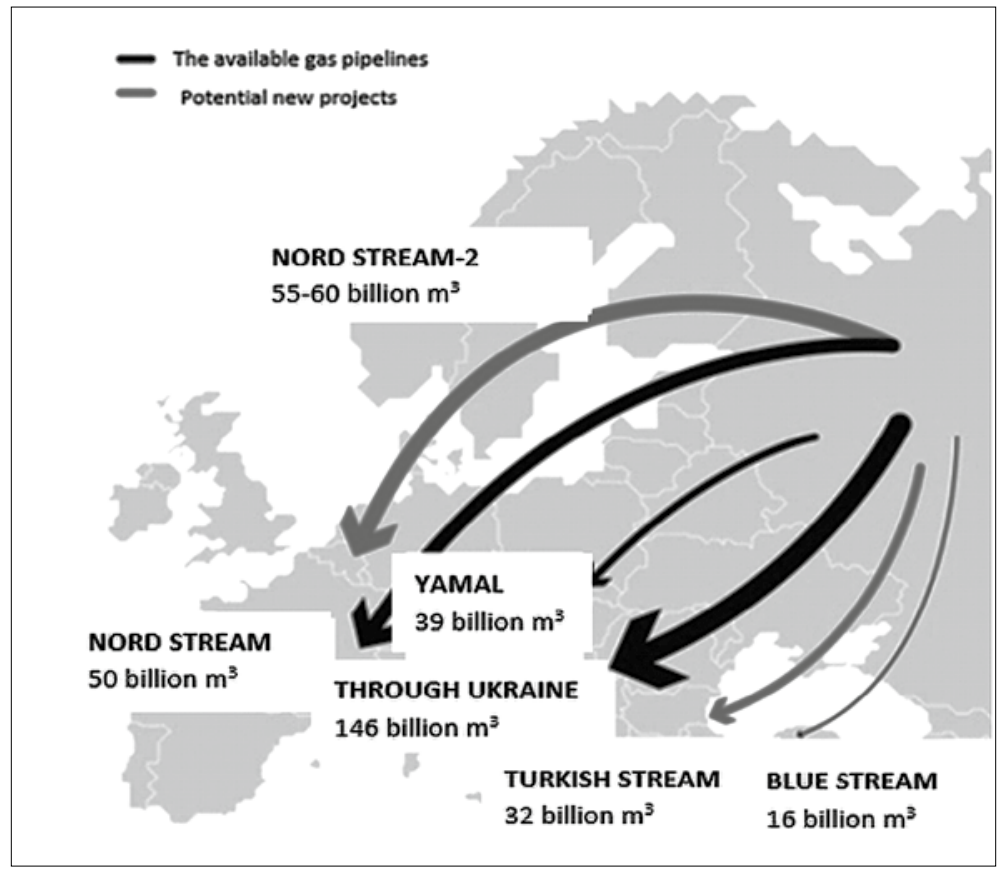

Source: AR 2016. First Sprouts [National Joint-stock Naftogaz, Ukraine] (2017), http://www. naftogaz.com/files/Zvity/Anual_report_ukr_170608.pdf

The pipeline will run through the territory of four EU member states: Finland, Sweden, Denmark, and Germany. To implement the project, it is necessary to obtain from each country a feasibility assessment, in particular that of the environmental issues. Germany and Gazprom insist that the project is a purely commercial agreement and should, therefore, be governed solely by German law on the land section of the pipeline, while European law does not apply to its offshore part (Germany revives Putin's pipeline dream 2017). Denmark and Sweden have asked the European Commission to clarify whether EU law on Nord Stream 2 should be fully implemented. In response to a request from the Scandinavian countries, the European Commission confirmed that the rules for implementing EU law, including the Third Energy Package, to the underwater gas pipelines are unclear. However, the European Commission stressed that Nord Stream 2 cannot be built and operate solely under Russian law and cannot exist in a legal vacuum. The European Commission has requested EU member states to negotiate with Russia on objections to Nord-stream 2, insisting on the extension of the basic 
principles of European energy law for the project, including its maritime section (Schmitt, 2019). Following the decision of the Polish antitrust regulator in 2016, Western participants withdrew from the partnership, although in 2017 Gazprom announced that the partners would still finance the project (National Permitting Processes..., 2017). However, it is unlikely that Gazprom will build the pipelines in the face of a full implementation of energy and antitrust laws.

They emphasize that Nord Stream 2 will not connect the EU with new gas sources, but will only change the direction of Russian gas flows from existing sources. As a result (1) Russian pipelines on the territories of Ukraine and Poland will become less effective due to less congestion; (2) an increasing concentration of Russian gas supplies into the Nord Streams; (3) given the stable projected demand for gas in the EU, Russia is likely to select those Dutch, British and Norwegian suppliers that are reducing production; (4) through Nord Stream 2, Russia will receive leverage to influence Germany as a transit country. It should be noted that the Yamal-Europe highway takes Russian gas to Europe through the territory of Belarus and Poland, so Poland acts as Ukraine's main ally in opposing the construction of Nord Stream 2.

The articulation of security problems in the context of the Nord Stream 2 pipeline is on the agenda both in European and Ukrainian political space. In particular, the European Parliament's Committee on Foreign Affairs (AFET) has amended the latest EU Commission report, "As the country [Ukraine] plays a crucial role in the European energy network, MEPs condemn the construction of the Nord Stream 2 pipeline as it is a political project that poses a threat to European security. Therefore, they urge to abolish the project implementation" ("Briefing EU Legislation in Progress", 2017). It is a top priority of both Ukraine and the EU to ensure energy security. This is evidenced by the appeal of MEPs, MPs (Joint open letter regarding Nord Stream 2 2018) and Ukrainian public organizations, but there are no collective decisions to strengthen coordination and consider mutual interests in the gas sector to address existing threats. One attempt that has not been made to date is the proposal of the national joint stock company, Naftogaz, of Ukraine in coordination with Ukraine's international partners to develop a road map in the event of a complete absence of natural gas transit through Ukraine to the EU after 2019.

Turkish Stream pipeline. Following Russia's refusal to build the South Stream gas pipeline project in early December 2014, the Russian side has publicly put forward the idea of implementing another similar one, dubbed the Turkish Stream pipeline. In mid-January 2015, at Gazprom headquarters in Moscow during a working meeting between the Deputy Head of the European Commission 
on Energy Union, Maroš Šefčovič, and the chairman of Gazprom, Alexey Miller, the latter stated that the construction of the Turkish Stream pipeline was a change in Gazprom strategy in the European gas market which is being built "based on a plan to create an energy union in the EU" (Miller: Turkish Stream..., 2015). Expanding on this idea, the Minister of Energy of the Russian Federation, Alexander Novak, warned the European Commission that it should start building its infrastructure as soon as possible in order to ensure gas delivery to its customers. As Novak clearly stated, "such work should be done as soon as possible as such large projects are not completed within one year. Furthermore, in order for consumers to receive gas in the medium term, it is necessary to start work today" (Energy: Resources and Markets..., 2015).

According to an interview in The Wall Street Journal, EU Energy Commissioner Šefčovič claimed that Russia was scheming to bypass Ukraine in the transit of gas and emphasized that it would never work. He argued that the new pipeline was being projected for $63 \mathrm{bcm}$ of gas which exceeds demand from Turkey and the countries of the Southeast Europe. Šefčovič also dismissed Gazprom's warning that Europe should begin construction of pipelines on the Turkish-Greek border now if it wants to receive gas after 2019 when the transit contract with Ukraine expires. He proceeded to say that Russia will have to reconsider this position and offer a viable economic solution that will be acceptable to European partners as well (Russian-US Energy Ministers Meetings, 2018).

However, the term of completion of pipeline construction and commissioning was set at December 2019, according to the 2016 Intergovernmental Agreement between Russia and Turkey. A dual-threaded marine gas pipeline from Russia to Turkey with a total volume of $31.5 \mathrm{bcm}$ per year consists of Russian land, maritime and Turkish land sections. The first strand of the pipeline is intended to supply gas to domestic consumers of the Republic of Turkey while the second strand will supply gas for export to Southern and South-eastern Europe. The project is being undertaken by South Stream Transport B.V. (Netherlands) (Prozorov, 2018, p. 7).

On November 30, 2019, Turkey's President, Recep Tayyip Erdogan, during the grand opening ceremony of the Tanap gas pipeline between Turkey and Azerbaijan, announced that the Turkish Stream pipeline is scheduled to be launched on January 8, 2020 (Ajans1, 2019). Importantly, this information applies only to the first gas pipeline strand intended to supply gas to domestic consumers of the Republic of Turkey. According to estimates by the director of GTS in Ukraine, Serhiy Makogon, the launch of the Turkish Stream gas pipeline for Ukraine means almost a complete stop in a southerly direction to Turkey and 
losses to Ukraine could amount to about 500 million dollars annually (GTS of Ukraine assesses risks..., 2019).

Although the second thread of the Turkish Stream pipeline is a project with cross-border implications for a number of EU countries, Poland, Slovakia, Hungary, Italy, Romania, as well as the Energy Community, and Ukraine and Moldova, it has not been discussed properly as a security issue so far in Ukrainian political discourse.

Stockholm Arbitration. From June 16, 2014, Gazprom introduced a prepayment regime for Ukraine and, at the same time, appealed to the Stockholm Arbitration (Arbitration Institute of the Stockholm Chamber of Commerce) with a request to pay for gas delivered. After a time, the number of claims, including requirements for payment of obligations of the Ukrainian company under the condition "take or pay" for 2012-16, were clarified. In response, Naftogaz of Ukraine appealed to the Stockholm Arbitration with a request for a retroactive review of the contract price for gas supply and compensation for all overpayments made since May 2011. In July 2014, these court cases were consolidated. More to the point, Naftogaz of Ukraine initiated an appeal for arbitration over the gas transit contract on October 13, 2014. In particular, the Naftogaz lawsuit alleges that relations between the parties are aligned with the state obligations of Ukraine in the implementation of the Third Energy Package.

Within the framework of the Stockholm Arbitration, the Transit Tribunal, in its decision of on February 28, 2018, acknowledged that Gazprom was obliged to pump the contracted volumes in 2009-2017 and on this basis, awarded Naftogaz $\$ 4.63$ billion compensation (Final Award..., 2018). Addressing the counterclaims between Naftogaz and Gazprom based on the arbitration proceedings on gas supply and gas transit contracts, the court found that Gazprom is to pay Naftogaz $\$ 2.56$ billion in cash and to pay interest on late payments. The Tribunal in its decision of 28 February 2018 did not support Naftogaz's requirement for a revision or application of regulated tariffs, and in particular, the Tribunal rejected Naftogaz's requirement that a gas transit contract should be in agreement with EU and Ukraine energy legislation, claiming that EU law is not relevant to this dispute, and that implementation of reforms in Ukraine is within the competence of the Ukrainian regulator. In a tariff review application in 2009, Naftogaz did not adhere to all the procedural requirements established by the contract for transit.

The Tribunal also rejected Naftogaz's requirement for the withdrawal of Naftogaz's rights and obligations under the transit contract of Ukrtransgaz and other legal entities designated by the GTS operator in Ukraine. To meet this 
requirement would allow Ukraine to save gas transit under the current contract and simultaneously to unbundle the GTS operator of Ukraine. The Tribunal noted that "the invalidation of the relevant contract provisions or the amendment of them falls within the scope of the regulator's powers, and only the regulator is entrusted to entrust mandatory control functions, granted the relevant competence and mechanisms to implement" (Final Award..., 2018).

In April 2018, Gazprom initiated new arbitration proceedings at the Arbitration Institute of the Stockholm Chamber of Commerce, effectively seeking to cancel the results of the arbitration awards or otherwise terminate gas supply and gas transit contracts. In turn, Naftogaz has put forward several counterclaims for Gazprom breaches of both contracts, for which the amount of compensation will be determined later. As a part of the arbitration proceedings for the gas transit contract, the Tribunal in its decision of February 28, $2018 \mathrm{did}$ not consider the Naftogaz request for a revision of the transit tariff as substantiated, as since the tariff review application in 2009 Naftogaz did not adhere to all procedural requirements established by the contract for transit. However, by the same decision, Naftogaz was not denied the right to request a tariff revision and accordingly, Naftogaz sent Gazprom a request for revision of the tariff in March 2018 by initiating negotiations according to the terms of the gas transit contract.

In 2018, the Arbitration Institute of the Stockholm Chamber of Commerce merged the case initiated by Gazprom to overturn previous decisions, with the case initiated by Naftogaz to review the tariff, into one proceeding. This decision of the Stockholm Arbitration is considered as a victory by Ukraine while the Russian side describes it as "ambiguous", for the Ukrainian part forgave the shortage of gas on the "take or pay" scheme, and the Russian side was fined for failure to meet the "pump or pay" condition, although the latter is stated only very implicitly in the contract.

Developing their natural ambiguity, Russian analysts emphasize that starting from "2019 it will be possible to try to turn over the conflict page in the two countries' gas disputes and start from scratch. Moreover, since the expiration of the signing of the Russian-Ukrainian gas contract, finally took shape the model of the European gas market with hub trading, virtual reversal opportunities, and other innovations have finally emerged. New standards, including for market transparency, are actively implemented by Naftogaz of Ukraine. All this creates additional opportunities for transparent relations under the new treaty".

Therefore, in terms of energy diplomacy, Ukraine, positioning itself as the winner in the confrontation with Russia at the Stockholm Arbitration, is 
attempting to prevent the launch of the Nord Stream 2 and the Turkish Stream pipelines.

\section{The energy diplomacy of Ukraine: decision-making and practice}

As a gas negotiating entity, Ukraine is strategically focused on gaining economic benefits and expanding its geopolitical resources. The purpose of this strategy is to preserve its status as a transit country for Russian gas and expand its functionality as a foreign policy tool. The transit contract with Gazprom is due at 10.00 on January 1,2020, which has stimulated a series of negotiations in a tripartite format, Export country (Russia) - Transit country (Ukraine) - Import countries (EU). Presently, there have been four rounds of negotiations, each of which has a symbolic bearing.

On 17 July 2018, representatives of the EU, Ukraine and Russia firstly met in Berlin to discuss the future format of Russian gas transit through Ukraine. The Vice-President of the European Commission on Energy Union, Šefčovič, stated that the core issue of gas negotiations between Ukraine, the EU, and the Russian Federation is the concluding of a new contract for the transportation of Russian gas via Ukraine to the EU after 2019. Summing up the results of the first round of the Ukraine-EU-Russia's talks, he stressed that all participants agreed to the need to concentrate efforts on a new gas transportation contract (Šefčovič, 2018).

Of critical value for Ukraine was the articulation on its further aspirations to European integration. In particular, there should be a harmonisation of Ukrainian energy legislation with the European which will positively affect future agreements, including the formation of tariffs for gas transit from Russia via Ukraine to the EU.

The second round of negotiations, hosted in Brussels on January 21, 2019 at top ministerial level from Ukraine, Russia and the European Commission, made a decision to postpone the negotiation process until May when the electoral process had been completed in Ukraine and Europe. But during the negotiations, the Ukrainian team drew the EU representatives' attention to the critical aspects of energy diplomacy. For example, the Minister of Foreign Affairs for Ukraine, Pavlo Klimkin, following the results of the second round of gas talks, stated that the Russian Federation does not want to comply with the Stockholm Arbitration decision and "Does not even consider the fact that we have completely different legislation, other rules, and other laws that comply with European legislation. ... And, of course, the Russian side does not recognize the decisions 
of the Stockholm Arbitration; it does not want to admit them. Legally, the situation has changed for all our European friends, but not for Russia" (Klimkin: no return to "contractors"..., 2019). In turn, the chairman of the Ukrainian board of Naftogaz, Andriy Kobolyev, added that the Russian side is looking for ways out of the situation on the litigation it lost in Stockholm. The successes of Ukrainian energy diplomacy have resulted in a change, albeit too slow, in the Russian position. "If the phrase 'restores balance' used to sound - now it sounds as 'zero option at the corporate level'. We are always open to any options, provided that they comply with the decisions already made in Stockholm and provide full fulfilment by the Russian side of their obligations under the two lost cases" (Kobolyev, 2019).

During the second round of gas talks the European Commission's position was the most constructive. In particular, Šefčovič stressed that Brussels made a fair offer to Moscow and Kyiv that the new contract should be long-term, for $10+$ years. The volumes must be commercially viable, as an investor in the organization and the upgrading of the Ukrainian gas transportation system (GTS) needed to be involved. The European Commission would also like them to be European companies with a high reputation (Šefčovič, 2019).

After a long pause, on September 19, 2019, the trilateral talks on gas transit between Ukraine, the European Commission and the Russian Federation were resumed. The main result was that the parties declared their readiness to continue discussing transit via Ukraine to the EU through 2020 under European rules i.e. retaining the capacity of the Ukrainian GTS. However, both the Ukrainian and the Russian sides stated that there are risks for disruption in future rounds. On the one hand, it may be a delay in the process of certification of the new GTS operator of Ukraine, on the other, the condition that Russia "nullifies" mutual requirements for the decision of the Stockholm Arbitration. The Russian side also raised the issue of resuming gas purchases directly by Ukraine.

Russia has confirmed its readiness to transmit gas to Ukraine via the EU, according to European rules, in particular, the Minister of Energy of the Russian Federation, Novak, confirmed, "Our position is that if European legislation is really implemented in January 2020, then we are ready to work in accordance with European legislation. This means that they are ready to reserve capacity from January 1, 2020" (Mitrova, Pirani \& Sharples, 2019). Representatives of the Ukrainian delegation told the press that such a conclusion was expected and optimal at this stage, as the gas transmission capacity is a fundamental difference between the European transit system and the one used for gas transit through Ukraine under the 2009 contract (Šefčovič, 2019). During the third round of 
negotiations, Russia again raised the issue of the Stockholm Arbitration decision, but did not adopt the consolidated position of the European and Ukrainian parties that the refusal to execute it could not be a prerequisite for the start of negotiations on a new gas transit contract.

The latest, fourth round of gas talks held on October 28, 2019, shows that the format of the consolidated position of Europe and Ukraine regarding the transit of Russian gas to Europe has been preserved. Among the key provisions of the joint position were the conclusion of a new agreement for the next period and the fixing of transit volumes which will ensure the reliable operation of the Ukrainian GTS. The contract should be concluded with the new operator of the Ukrainian GTS which will be withdrawn from the Naftogaz Group on January 1, 2020. In doing so, relations between the GTS Operator of Ukraine and Gazprom should be built on the requirements of European energy legislation, which Ukraine implements as a member of the Energy Community.

During the negotiations, the European Commission proposed that Ukraine and the Russian Federation conclude two treaties "Belief in the interconnector and the contract of transportation". Appraising the proposal, the Minister of Energy and Environment, Oleksiy Orzhel, emphasized that Ukraine supports the proposal of European colleagues while maintaining a clear position on "ensuring security of supply in the region, ensuring stable supply to European markets, as well as stable volumes required for work gas transmission system" (The EU has proposed a scheme..., 2019).

Despite the optimism and willingness of Ukraine and Russia to discuss the gas contract, the European Commission was disappointed by the result of the consultations that were held in Brussels on October 28 ${ }^{\text {th }}, 2019$. "I had prepared the meeting so that in the presence of political will there could be positive progress" (Trilateral Gas Talks with Russia and Ukraine..., 2019), noted the Vice-President, nevertheless, the parties failed to move forward. In particular, the methodology of tariff setting for gas transportation, published on October $25^{\text {th }}$ by the Ukrainian regulator of National Commission for State Regulation in Energy and Utilities, was not approved and no arrangement was reached on the signing of the technical agreement between the operators of the gas transportation systems of Russia and Ukraine. He added that Kyiv was ready to discuss gas solutions including direct Russian gas purchases and settlement agreements on litigation, while Russia was not willing to discuss the specific parameters of gas transit contracts, offering to resolve all issues by a package. The Head of the Delegation of the Russian Federation, Energy Minister Novak, confirming his willingness to cooperate with Ukraine on the basis of European legislation, 
offered to agree officially with Kyiv on all issues related to gas: transit, supply and arbitration. In response, the Ukrainian delegation made clear that the complex proposal was inadmissible, since Russian gas supplies to Ukraine and lawsuits were issues that must be resolved in a bilateral format between Gazprom and Naftogaz. Ukraine is ready to buy gas from Russia, but only on favourable terms for both parties and at a competitive price.

Four rounds of tripartite negotiation in the format Export country (Russia) Transit country (Ukraine) - Import countries (EU) have convincingly shown that without the diplomatic support of the EU, maintaining Ukraine's geopolitically significant status as a transit country is problematic. It is worth emphasizing that under the influence of the EU position, Ukraine has transformed its vision of the process of reaching an agreement with Russia on a new gas contract from non-acceptance of a package to readiness for a complex procedure discussion.

\section{Conclusion}

European energy diplomacy rules presuppose the ability to take into account the interests of the parties, including the interests of Ukraine, which comply with EU legislation and should be considered as an integral part of the EU gas market. With a powerful resource, the transit country's gas transportation system, Ukraine needs to concentrate all its efforts on maintaining its status as a geopolitical player. However, playing by EU rules requires from Ukraine compliance with EU standards regarding the organization of gas production and transportation. In late 2019, Ukrtransgaz is the operator of Ukraine's gas transmission system, $100 \%$ owned by Naftogaz. As a result of the implementation of the "Natural Gas Market", the new Ukrainian regulations, the GTS operator must be separated from Naftogaz, which means that the GTS operator must be legally and organizationally independent from other activities in the natural gas market. This requirement had to be fulfilled by July 1, 2016. However, it was only in July 2016 that the Government of Ukraine approved an action plan to separate the management of the GTS from the Naftogaz Group. The plan envisages that these functions will be transferred to a newly created company, completely independent of Naftogaz, but these processes are incomplete. So, the tripartite negotiations are about signing a new transit agreement between Gazprom and the Ukrainian GTS operator, status of the latter company remains open.

Energy security in Ukraine and the EU is interconnected and interdependent. The analysis of the deployment of Ukraine's energy diplomacy demonstrates that 
there are a number of factors which negatively affect the security of gas supplies to both Ukraine and the EU. In particular, Gazprom Nord Stream 2 pipeline and Turkish Stream projects are being implemented rapidly and related infrastructure projects are destroying the foundations of the European gas market; there is contractual uncertainty regarding the provision of gas transportation services to the EU using GTS in Ukraine; the risks of depriving Ukraine of the status of a gas transit country have been formed which would affect its geopolitical position. Despite the provisions of the Association Agreement which allow coordination of joint actions on gas infrastructure, which is important to counteract the Nord Stream 2 pipeline project, the joint implementation of the objectives of the agreement by Ukraine and the EU is limited at present.

Currently, Ukraine has been developing a proactive energy diplomacy strategy, facing external challenges and threats; meanwhile playing the crucial role of a strategic geopolitical gas-transit country, Ukraine requires the use of proactive strategies to advance the agenda for European energy security. To conclude, it is necessary that Ukraine should vigorously design suitable energy diplomacy as effective tools for improving energy security both on national and European levels.

\section{REFERENCES}

A Framework Strategy for a Resilient Energy Union with a Forward-Looking Climate Change Policy. (2015, Feb 25). Brussels, 25.2.2015 COM(2015) 80 final. Retrieved from https://eur-lex.europa.eu/resource.html?uri=cellar:1bd46c90-bdd4-11e4-bbe101aa75ed71a1.0001.03/DOC_1\&format=PDF

Agreement on an International Energy Program. (2007). Retrieved from https://www. ebv-oil.org/cms/pdf/iep.pdf

Ahmed, G., Abdulsamd, A., Gereffi, G., \& Daly, J. (2014). What Role Can Coal Play in the United States Energy Future? The Electricity Journal, 27(3), 87-95.

Ajansı, A. (2019, Nov 30). Cumhurbaşkanı Erdoğan: Hiçbir ülke uluslararası hukuktan üstün değil. NTV. Retrieved from https://www.ntv.com.tr/turkiye/cumhurbaskanierdogan-hicbir-ulke-uluslararasi-hukuktan-ustun-degil,hqpAsEth-UahVFBIhZHSqg

Annual report 2017. A historic victory and the beginning of the transformation of the [national joint campaign NAFOGAZ of Ukraine]. (2018). Retrieved from http://www. naftogaz.com/files/Zvity/NAK_AnRep2017_UA.pdf

Annual report 2018. Strengthen yourself - Ukraine [national joint campaign NAFOGAZ of Ukraine]. (2019). Retrieved from http://www.naftogaz.com/files/Zvity/AnnualReport-2018-ukr.pdf 
Annual Report and Form 20-F 2016. (2017). Retrieved from https://www.equinor.com/ en/investors/our-dividend/annual-reports-archive.html

Annual report of 2016. The first stirrings of the [national joint campaign NAFOGAZ of Ukraine]. (2017). Retrieved from http://www.naftogaz.com/files/Zvity/Anual_report_ukr_170608.pdf

AR 2016. First Sprouts [National Joint-stock Naftogaz, Ukraine]. (2017). Retrieved from http://www.naftogaz.com/files/Zvity/Anual_report_ukr_170608.pdf

Auer, J. (2007). EU Energy Policy: High Time for Action! Deutsche Bank Research, EU Monitor, 44. Retrieved from https://www.eesc.europa.eu/sites/default/files/resources/ docs/deutsche_bank_eu_energy_policy.pdf

Bayou, C. (2007). L'europe et la diplomatie énergétique du pouvoir russe défiances et dépendances. Revue Internationale Et Strategique, 68(4), 175-186.

BP. (2019). BP Statistical Review of World Energy. Retrieved from https://www.bp.com/ content/dam/bp/business-sites/en/global/corporate/pdfs/energy-economics/ statistical-review/bp-stats-review-2019-full-report.pdf

Briefing EU Legislation in Progress. (2017). Retrieved from https://www.europarl.europa. eu/RegData/etudes/BRIE/2017/599243/EPRS_BRI(2017)599243_EN.pdf

Chaban, N., \& Knod, M. (2015). Energy diplomacy in the context of multistakeholder diplomacy: The EU and BICS. Cooperation and Conflict, 50(4), 457-474.

Cleutinx, C., \& Piper, J. (2008). The EU-Russia Energy Dialogue. In Pipelines, Politics and Power: The Future of EU-Russia Energy Relations (pp. 25-33). London: Centre for European Reform.

Constantinou, C., Kerr P., \& Sharp, P. (eds.). (2016). The SAGE Handbook of Diplomacy. Sousand Oaks: SAGE Publications Inc.

Delivery statistics. Gas supplies to Europe. (2018). Retrieved from http://www.gazpromexport.ru/en/statistics/

Description of the gas-transport system of Ukraine. (2019). Retrieved from http://utg.ua/ utg/gts/description/

Energy: Resources and Markets. Turkish Stream what Strategy for Europe. (2015). Retrieved from https://www.econstor.eu/bitstream/10419/113951/1/NDL2015-050.pdf

Final Award. SCC Arbitration no. V2014/129. (2018). Retrieved from http://www.naftogaz.com/files/media/Transit\%20Award_Redacted.pdf

Gas prices by type of user. EUR per gigajoule. Data browser. Beta. (2019). Retrieved from https://ec.europa.eu/eurostat/databrowser/view/ten00118/default/table?lang=en

Karnitschnig, M. (2017, Dec 12). Germany revives Putin's pipeline dream. Politico. Retrieved from https://www.politico.eu/article/germany-revives-putins-pipelinedream/

Goldstone, P. R. (2007). Pax Mercatoria - Does Economic Interdependence Bring Peace? The Audit of Conventional Wisdom, 7, 1-4.

GTS of Ukraine assesses risks from Turkish Stream. (2019, Aug 28). Unian. Retrieved from https://www.unian.ua/economics/energetics/10664901-operator-gts-ukrajiniociniv-riziki-vid-tureckogo-potoku.html 
Hartley, P., \& Medlock III, K. (2006). The Baker Institute World Gas Trade Model. In D. Victor, A. Jaffe \& M. Hayes (eds.), Natural Gas and Geopolitics: From 1970 to 2040 (pp. 357-406). Cambridge: Cambridge University Press.

International Energy Agency. Energy security. (2019). Retrieved from https://www.iea. org/topics/energysecurity/

Joint open letter regarding Nord Stream 2. Brussels, 5 November 2018. (2018). Retrieved from https://reinhardbuetikofer.eu/2018/11/06/gemeinsamer-offener-brief-zu-nordstream-2/10

Klimkin: no return to "contractors" with Russia on gas transit [Video]. (2019, Jan 21). Retrieved from https://www.radiosvoboda.org/a/29722858.html

Kobolyev, A. (2019). Russia is looking for a way out after a double loss in Stockholm. Retrieved from https://www.ukrinform.ua/rubric-economy/2624188-evrokomisiazrobila-cikavu-tranzitnu-propoziciu-naftogaz.html

Larsson, R. (2006). Russia's Energy Policy: Security Dimensions and Russia’s Reliability as an Energy Supplier. Retrieved from http://www2.foi.se/rapp/foir1934.pdf

McSweeney, B. (1996). Review: Identity and Security: Buzan and the Copenhagen School, Review of International Studies, 22(1), 81-93.

MEPs want deeper EU ties with Ukraine, Georgia and Moldova. (2017, Nov 7). Retrieved from https://www.europarl.europa.eu/news/en/headlines/priorities/ukraine /20171030STO87111/meps-want-deeper-eu-ties-with-ukraine-georgia-and-moldova

Miller: Turkish Stream will replace transit through Ukraine. (2015, Jan 14). Retrieved from https://www.bbc.com/russian/rolling_news/2015/01/150114_rn_gazprom_turkey_eu

Mitrova, T., Pirani, S., \& Sharples, J. (2019, Nov). Russia-Ukraine gas transit talks: risks for all sides. https://www.oxfordenergy.org/wpcms/wp-content/uploads/2019/11/Russia -Ukraine-gas-transit-talks-risks-for-all-sides-Insight-60.pdf? $\mathrm{v}=3943 \mathrm{~d} 8795 \mathrm{e} 03$

Naftogaz. Annual Report 2014. Changes for the Future. (2015). Retrieved from http:// www.naftogaz.com/files/Zvity/Naftogaz\%20Annual\%20Report\%202014.pdf

National Permitting Processes. Nord Stream 2 AG. (2017). Retrieved from https://www. nord-stream $2 . \mathrm{com} / \mathrm{ru} / \mathrm{dlia}$-pressy/dokumenty/?page $=6$

Pirani, S., Stern, J., \& Yafimava, K. (2009). The Russo-Ukrainian gas dispute of January 2009: a Comprehensive Assessment. Oxford: Oxford Institute for Energy Studies.

Proedrou, F. (2017). Revisiting pipeline politics and diplomacy: from energy security to domestic politics explanations. Problems of Post-Communism, 2, 1-10.

Prozorov, S. (2018). Turkish stream. Gazprom. Gazprom Corporate Magazine, 12, 6-10. Report on the Implementation of the European Security Strategy-Providing Security in a Changing World (11 December 2008, S407/08). Brussels: the European Council. Retrieved from https://www.consilium.europa.eu/uedocs/cms_data/docs/pressdata/ en/reports/104630.pdf

Russian-US Energy Ministers Meetings. (2018). Retrieved from http://theopinion.net/ russian-us-energy-ministers-meetings?action=print 
Schmitt, B. L. (2019, Dec 9). The Neue Ostpolitik approach to Nord Stream 2: A legal fiction carried a little too far. Retrieved from https://www.atlanticcouncil.org/ blogs/energysource/the-neue-ostpolitik-approach-to-nord-stream-2-a-legal-fictioncarried-a-little-too-far/

Scott, R. (1994) IEA. The first 20 years. Vol. 1. Origins and structure. Paris: OECD/IEA. Retrieved from https://www.iea.org/media/about/lieahistory.pdf

Šefčovič, M. (2019, Jan 21). Statement by Vice-President for Energy Union Maroš Šefčovič following the trilateral talks with Russia and Ukraine on the future of gas transit via Ukraine. Retrieved from https://ec.europa.eu/commission/presscorner/ detail/en/STATEMENT_19_562

Shared Vision, Common Action: A Stronger Europe. A Global Strategy for the European Union's Foreign and Security Policy. (2016). Retrieved from http://eeas.europa.eu/ archives/docs/top_stories/pdf/eugs_review_web.pdf

Simoniya, N., \& Torkunov, A. (2015). The European Union's Energy Security and Russia. Social Sciences. Quarterly Journal of the Russian Academy of Sciences, 2, 78-89.

Study of the EU's energy diplomacy: Transatlantic and foreign policy implications. (2016). Retrieved from https://op.europa.eu/en/publication-detail/-/publication/02c52db6e8f1-41f6-84c2-bc354bf098fd

The EU has proposed a scheme for a transit agreement between Ukraine and Russia Orgel. (2019, Oct 28). Ukrainska Pravda. Retrieved from https://www.epravda.com. ua/news/2019/10/28/653064/

Timeline: Parliament's continued support for Ukraine. (2017). Retrieved from https://www. europarl.europa.eu/news/en/headlines/priorities/ukraine/20170324STO68409/ timeline-parliament-s-continued-support-for-ukraine

Trilateral Gas Talks with Russia and Ukraine. Press briefing by Vice-President Maroš ŠEFČOVIČ following the Trilateral Gas Talks with Russia and Ukraine [Video]. (2019, Oct 28). Retrieved from https://audiovisual.ec.europa.eu/en/topnews/M-003546

Zhiznin, S. (2010). Russian energy diplomacy and international energy security (geopolitics and economics). Baltic Region, 1, 7-17. 